\title{
AN ACTIVE APPROACH AS PART OF THE CREATION OF URBAN AND LANDSCAPE SPACE
}

\author{
VÁCLAV ŠANA
}

Brno University of Technology, Faculty of Architecture, Poříčí 5, 63900 Brno, Czech Republic Tutor: Ing. arch. Kateřina Dokoupilová Pazderková, Ph.D.

Theme of the dissertation: Water areas as potential for city/village activities vsana@seznam.cz

\begin{abstract}
Throughout history, the concept of the urbanist points to the figure of an almighty, authoritative planner who creates spaces. The ambition of a perfect design is met by random external factors, which fundamentally affect the final results. Thus, another component of the active approach of individuals or movements enters the creation. The application of ecological, mobility, cultural and social topics creates a contrast to the technocratic planning of cities and landscapes. This article broadly presents cases of an active approach to urbanism and reflects the holistic profession of an urbanist in a contemporary context.
\end{abstract}

KEY WORDS: urbanism, space, activism, active approach, the city, landscape

\section{Authoritative urbanism in history and the present}

Since ancient times, significant urban structures have pointed to the urban planner's figure as an urbanist who creates idealized urban structures through authoritarian power. Different historical periods emphasize different types of political power. We can mention the circular urban master plan of Baghdad in the eighth century, the planning of urban fortresses exactly according to the idealized military urbanism of the French Baroque architect Vauban, the urban grid of so-called blocks as a presentation of the Yugoslav Socialist State in New Belgrade, or the magnificent infrastructure as a manifestation of successful personal mobility from the authoritative official Robert Moses. 
Various political ambitions give rise to urban structures based on idealized ideas and theories of urbanism.

In the modern era of the 20th century, the dynamic development and transformation of society have opened up new idealized ideas in urban planning. One of the most important summaries of these ideas took place in 1943 at the CIAM conference in Paris and came to consciousness as the Athens Charter (Hrůza 2002). The principles of modern urbanism introduced by Le Corbusier provided strict rules, not only for the construction but also the reconstruction of existing cities. Delimitation was replaced by a new functional and technical manifesto concerning the old imperfect and artificial world.

Unrealized plans, such as the Plan for a "Ville Contemporaine", a city for 3 Million inhabitants, the "Plan Obus", the reconstruction of central Paris, "Voisin Plan", came to be considered interesting urban thinking over time, but too radical and unsuitable for implementation.

Despite criticism at the end of the 20th century, the legacy of modernist ideas lives on in various forms. Thanks to dynamic development and growing demographics, the countries of the Second and Third Worlds are opening up to unequivocal strict construction, which is being addressed by increasing urbanization.

Often such construction becomes a symbol of the positive development of a country. We can mention greenfield project cities like Brasilia in Brazil, Islamabad in Pakistan and Canberra in Australia.

At present, Indonesia's ongoing problems have forced the government to build a new, more strategic capital, East Kalimantan (South China Morning Post 2019). The overcrowding of a continuous megalopolis in the Nile Valley also led to the decision to build a new capital for 7 million, New Cairo (The B1M 2019).

The last two examples show that the legacy of authoritarian urbanism through the planning of idealized cities is realized in some countries even after general professional criticism of modernist urbanism and the drafting of the New Athens Charter of 2003.

\section{Idealized urbanism and external "spontaneous" influences}

In general, the time-consuming process of urban design, trying to cover as many aspects as possible, despite its complexity, cannot describe all the factors. Also, mod- 
ernist urbanism has failed to respond to new problems that only arise after a certain length of time.

Theorist and critic Charles Jencks said the „death of modernism“ took place in 1972 during the demolition of the Pruitt-Igoe housing estate in Saint Louis. (Moore 2012)

Strict urban interventions enforced by authoritarian political powers intensify external criticism of such proposed urbanism. The urban planner is only able to react to these problems after a significant time lag, and cannot be sure that they have not made a new mistake with their intervention.

\section{Active approach urbanism hypothesis}

Thanks to more stable demography and a favourable economic situation, there is a general social impression in "first world“ countries from the end of the 20th century that the current state of urban development and interventions in the landscape is sufficient enough and does not need to be changed. Existing residents are looking for stronger interventions in cities and landscapes after historical experiences of distrust.

In addition, thanks to democratic functioning and participation, they have the opportunity to intervene in the external construction plan through protests, petitions or their political movements. The term "Not In My Backyard" was introduced in the " $80 \mathrm{~s}$ in the USA and is a common phenomenon in today's cities. The opposite approach is "Yes In My Backyard".

Both approaches can not only be used by active citizens, but also by architects and urban planners in proposed interventions in cities and landscapes. Here, the creation of cities is not only through the intervention of the city planner but also through an active approach, in order to enforce and defend its proposition before the administrative authorities and the general public.

The stated hypothesis is that the profession of a graduate of architecture and urbanism in the context of the dynamic 21st century does not give a clear direction in which the given expert should go. One of the possibilities is to take the path of a holistic activist who is aware of his knowledge and tries to apply it in the non-hierarchical creation of urban spaces. This is the opposite state of the city planner, who only fulfils the assignment of political and financial lobbyism. 


\section{Four contexts of active approach - hypothesis}

This article comes with a hypothetical determination of various forms of active approach in urbanism. These are 4 areas that urban planners could work with. This approach distinguishes them from the individual's idea of the individual in the context of scale, place and ideology.

\section{Ecological context (Nature)}

Urbanization, mechanization and mobility arise mainly at the expense of the natural biosphere. Mankind's more excessive demands on material resources such as drinking water, food and energy are reflected in the state of the environment. In addition to local negative interventions in the landscape, there is an increasingly serious climate crisis with extreme weather events.

Efforts to preserve landscape areas from negative intervention are complemented by protests against the very functioning of society. The ecological aspect is of particular interest to ecological activist groups. On a larger scale, however, it is a strong element in the organization of the landscape and thus urban work with space.

Efforts to preserve natural watercourses before the construction of dams can be understood as the clash with authoritarian intervention through the technical perception of nature as a material source, and the ecological perception of the landscape

In May 2020, in response to the protracted drought, the Czech Ministry of Agriculture presented a plan to build 31 water reservoirs. From the very beginning, this plan has been criticized by the professional public as inadequate and erroneous in the current situation. Critics have pointed out that water is more environmentally friendly and more efficient to retain in a landscaped landscape. One of the critics was Jiří Malík, who is the chairman and founder of the "Živá voda" association, which tries to retain water directly in the landscape through minor interventions by volunteers. "We have to make a dam out of our whole country." (Zabloudilová 2020)

\section{Transport context (Mobility)}

The mobility of the population and goods creates the view of the planet as one large sophisticated logistics network. The construction of infrastructure seems to be a necessary part of the company's development. The necessary construction seems to be a major intervention in the existing urban and landscape environment, making it a strong topic for an active approach. 
The motive for preventing the construction of a large infrastructure project may be an effort to preserve the existing environment, or a general preference for more environmentally friendly transport. In the urban environment, activists take advantage of the current trend in mobility, which favours public transport and cycling over individual motoring.

The context of transport can result in interesting examples, one of which is described in the book Steel Cities (FREJLACHOVÁ, PAZDERA, ŘíHA 2019). This book describes the extensive construction of logistics centres in the last decade in the Czech Republic. The country's advantageous geographical position gave rise to large-capacity warehouses. Cheaper land and the availability of manpower have caused infrastructure demands for the transport of goods, which are only stored in the Czech Republic and travel abroad to the target customer.

\section{Cultural context (Heritage)}

An active effort to preserve the already existing monumental character of urban spaces. The expert knowledge of an urban planner can hierarchize the given value of spaces and buildings.

"From a cultural point of view, such a radical intervention as demolition is the worst option. It is better to understand the existing situation, estimate the strengths and try to improve them slightly." This is the view of the architect Anne Lacaton, who won the Pritzker Prize for 2021 with her partner. This is evidenced by a practical example from her career, the assignment to "beautify" the square in Bordeaux. After a long observation, the architects decided that the space works as it should and therefore will not interfere with it in any way. (Gebrian 2014)

\section{Social context (Society)}

Apart from material creation, urbanism itself works strongly with the social structure of social space. The phrase "The right to the city", defined by the sociologist Henri Lefebvre, was placed above all man's interaction in the creation of cities. (Coleman 2015)

Negative factors affecting contemporary cities such as gentrification, financialization, over-tourism or housing crises are recurring in various forms around the world. These are global problems that secondarily cause tensions in society.

Journalist Jane Jacobs emphasized urbanism created from the bottom through an ac- 
tive approach. The dispute over Greenwich village shows a clash of opposing views on the functioning of cities. Jacobs wrote a highlight of multifunctional spaces in contrast to the monofunctional structure in her iconic book Death and the Life of American Cities (Jacobs 1961).

\section{Conclusion}

The defined active approach in the creation of urbanism is in the mentioned examples a very significant and indispensable component in the creation of the overall urban space and landscape. The hypothesis of the division of influences into social, cultural, transport and ecological components is a very useful tool for research into the active approach, but it is an unclear tool. The individual 4 contexts are left not as separate elements, but as a sophisticatedly interconnected package. For example, propositions in terms of mobility in urbanism are becoming a social issue and vice versa.

The following research can examine the effectiveness of a pro-active approach in the context of 21st century global challenges such as the climate crisis, which is directly related to the work of the urban planner. Ambitious and comprehensive urban transformation plans raise the fundamental question of whether it is not better to use an authoritative intervention rather than a proactive approach.

\section{Sources}

HRŮZA, Jiří. Charty moderního urbanismu. Praha: Agora, 2002, 94 s. ISBN 80902945-4-5.

Indonesia picks winning design for its new capital, South China Morning Post - Youtube [online] 2019-09-27 cit. 2021-09-08 available from https://www.youtube. com/watch?v=7-B-jTss5WA.

Building Egypt's \$58BN New City in the Sand, The B1M - Youtube [online] 2019-1002 cit. 2021-09-08 available from https://www.youtube.com/watch?v=P0fkucDtTRE

MOORE, Rowan, Pruitt-Igoe: death of the American urban dream, Guardian [online] cit. 2021-09-12 available from https://www.theguardian.com/artanddesign/2012/feb/26/pruitt-igoe-myth-film-review

ZABLOUDILOVÁ, Táňa, Vrátit vodu tam, kde byla. V Česku vzniká sít lidí, kteří se učí tvořit .... A2larm [online] cit. 2021-09-08 available from https://a2larm.cz/2020/12/vratit-vodu-tam-kde-byla-v-ceskuvznika-sit-lidi-kteri-se-uci-tvorit-tune-a-mokrady/

FREJLACHOVÁ, Kateřina, Miroslav PAZDERA, Tadeáš ŘíHA, et al. Steel cities: the architecture of logistics in Central and Eastern Europe = Ocelová města. Praha: 
Curych: Galerie VI PER ; Park Books, 2019, 360 s. ISBN 978-80-270-7038-1.

GEBRIAN, Adam, Architektka Anne Lacaton: Bourání je nejhorší možnost... Radio Wave [online] cit. 2021-09-12 available from https://wave.rozhlas.cz/architektka-anne-lacaton-bourani-je-nejhorsi-moznost-5271909

COLEMAN, Nathaniel. Lefebvre for architects. London ; New York: Routledge, 2015, xvii, 153 s. :ISBN 978-0-415-63940-8.

JACOBS, Jane a Jana SOLPEROVÁ. Smrt a život amerických velkoměst. 2., aktualiz. a dopl. vyd. Dolní Kounice: MOX NOX, 2013, 479 s. ISBN 978-80-905064-4-2. 